\title{
Soil Management Systems: Effects on Soil Properties and Weed Flora
}

\author{
G. Ferrara ${ }^{*}$, A. Mazzeo ${ }^{1}$, A.M.S. Matarrese ${ }^{1}$, A. Pacifico ${ }^{1}$, M. Fracchiolla ${ }^{2}$, Z. Al Chami ${ }^{3}$, C. Lasorella ${ }^{2}$, P. Montemurro ${ }^{2}$, \\ D. Mondelli ${ }^{1}$
}

(1) Dipartimento di Scienze del Suolo, della Pianta e degli Alimenti - University of Bari 'Aldo Moro', Via Amendola 165/A 70126 Bari (Italy)

(2) Dipartimento di Scienze Agro-Ambientali e Territoriali - University of Bari 'Aldo Moro', Via Amendola 165/A - 70126 Bari (Italy)

(3) CIHEAM, Mediterranean Agronomic Institute of Bari, Via Ceglie, 9 - 70010 Valenzano (Bari), Italy

Submitted for publication: April 2014

Accepted for publication: August 2014

Key words: Exhausted olive pomace, soil, weeds, mulching

\begin{abstract}
A three-year experiment was conducted in order to evaluate the effects of three different soil management systems in a vineyard (organic mulch with exhausted olive pomace at $6 \mathrm{~cm}$ thick, weed mowing and herbicide application) on soil physicochemical characteristics and weed flora. A variety of data was collected throughout the trial, such as soil analyses, weed surveys and phytotoxicity tests. The results show that the exhausted olive pomace was able to increase the $\mathrm{K}$ and $\mathrm{Mg}$ content and exerted good control over weeds, and also had an effect on the weed flora composition. Although further research is needed, it is possible to conclude that the mode of action of the exhausted olive pomace was both mechanical (thickness of the layer) and phytochemical for the release of phytotoxic compounds (allelochemicals).
\end{abstract}

\section{INTRODUCTION}

It is well known that weeds are responsible for yield losses in vineyards and orchards because they compete with plants for nutrients and water and may reduce crop yields by up to $80 \%$ (Cousens \& Mortimer, 1995). Traditional control of weeds is by soil tillage, but chemical control of weeds using preand post-emergence herbicides is widely used. Chemical control is particularly effective to control weeds in the vine rows, where it is difficult to operate mechanically, whereas vegetation can be controlled easily by mowing or disking in the work row. However, reasons for reducing herbicide use are the widespread appearance of herbicide-resistant weeds (Darmency \& Gasquez, 1990; LeBaron \& McFarland, 1990; LeBaron, 1991; Henkes, 1997; Powles et al., 1997), the risk of environmental contamination (Carter et al., 1991) and, more recently, the very negative public perception of agrochemicals (Major, 1992) as affecting the environment and food quality.

Mulching consists of spreading a protective layer of a material of different origin and nature over the soil. Several materials can be used for mulching: synthetic (i.e. geotextile), organic (i.e. straw, pruning residues, etc.,) and living (i.e. cover crops).

Weed suppression by living or dead mulches can be due to a mechanical action (i.e. the thickness of the layer) and, in some cases, to the release of allelochemicals (Teasdale \& Mohler, 2000; Bhowmika \& Inderjit, 2003; Moonen
\& Barberi, 2010). However, because organic mulches decompose over time, they require periodic applications, with consequent costs and the availability of the material becoming a potential problem. On the other hand, organic and living mulches can provide organic matter and nutrients to the soil and enhance soil particle aggregation and water-holding capacity (Haynes, 1980; Merwin et al., 1995; Verdú \& Mas, 2007). Moreover, higher yields have been reported in mulched vineyards with respect to conventional vineyards (Van Huystteen \& Weber, 1980). The use of mulching materials also should be considered as a tool for the economical and sustainable use of waste materials. Olive mill waste disposal is an important issue for the Mediterranean olive oil-producing countries. In Italy, olive pomace commonly is produced from three-phase systems, which are preferred to two-phase systems because olive pomace is extracted successively with n-hexane for obtaining olive pomace oil. The so-called exhausted olive pomace is then mostly used as fuel for the oil extractors and for domestic heating, since it has a high calorific value. However, this material could find a possible application in organic agriculture, especially in the countries where it is largely produced. In recent years, EU policy to support more sustainable agricultural practices has shown an increased and keen interest in the value of agricultural by-products such as olive pomace. As a consequence, a number of investigations on the agronomic utilisation of olive pomace have been

*Corresponding author: E-mail address: giuseppe.ferrara@uniba.it [Tel.: +39 080 5442979; Fax: +39080 5442979] 
undertaken. In particular, the use of olive pomace as soil amendment material, especially after composting, showed positive effects on various soil properties (Saviozzi et al., 2001; Rinaldi et al., 2003; Brunetti et al., 2005; Alburquerque et al., 2006; López-Piñeiro et al., 2008; Ferrara et al., 2012; Gómez-Muñoz et al., 2013).

The objective of this study was to compare three different soil management systems in the vine row: (1) exhausted olive pomace mulch; (2) weed mowing; and (3) chemical control (herbicides). Effects on soil chemical properties and weed control efficacy were investigated.

\section{MATERIALS AND METHODS}

\section{Plant material and experimental design}

The study was carried out from 2008 to 2010 in the repository of table and wine grape cultivars (more than 100 varieties and clones) located in the Department of Soil, Plant and Food Science at the Experimental Agriculture Station of the University of Bari, 'Aldo Moro', in Valenzano (Puglia Region, South-eastern Italy). The vineyard was planted in 2002 and the vines were spaced $1.0 \mathrm{~m} \times 4.0 \mathrm{~m}$, trained onto a Guyot system with a 1103 P rootstock and drip irrigated from May to September (600 to $800 \mathrm{~m}^{3} / \mathrm{ha}$ ). For each row, a single irrigation pipeline was positioned at a height of $50 \mathrm{~cm}$ from the soil with two drippers for each vine (distance $0.5 \mathrm{~m}$ each from the vine). Pest control and other vineyard operations were conducted according to local practices. Fertiliser application was suspended for the three years of experimentation in order to better verify the effects of the different weed management practices on the organic and mineral element content of the soil.
The alleyways between the rows were mowed or disked, whereas the following floor management systems were compared in the rows:

- exhausted olive pomace of $6 \mathrm{~cm}$ thick (EOP6) applied under the vines (Fig. 1);

- $\quad$ mowing, two to three times per year (WM);

- chemical control using glyphosate at $1080 \mathrm{~g} /$ ha active ingredient, applied two times per year, in autumn and spring (CC).

Each treatment was repeated in six plots, consisting of one row $24.0 \mathrm{~m}$ long and $1.0 \mathrm{~m}$ wide, in a randomised block design. The application of the exhausted olive pomace was performed at the end of the winter of the year 2007. On the basis of the density of the olive pomace $\left(500 \mathrm{~kg} / \mathrm{m}^{3}\right), 720 \mathrm{~kg}$ were applied for each plot (replicate).

\section{Soil analyses}

Soil chemical analyses were performed each year following internationally recommended procedures (Sparks et al., 1996). In particular, soil samples were collected in autumn 2007 and successively in the autumn of each year, from 2008 to 2010 , at a distance of around $0.25 \mathrm{~m}$ from the vine and the dripper. Plant residual materials were removed accurately, and the soil was air-dried, gently crushed, and passed through a $2 \mathrm{~mm}$ sieve. Stones and gravel were removed and determined.

The analysis of particle size was performed using the pipette method according to Gee and Bauder (1986), and the textural classes were determined using the textural triangle of the USDA classification scheme.

Soil $\mathrm{pH}$ was determined in water $\left(\mathrm{pH}_{\mathrm{H}_{2} \mathrm{O}}\right)$ and in $0.01 \mathrm{M}$

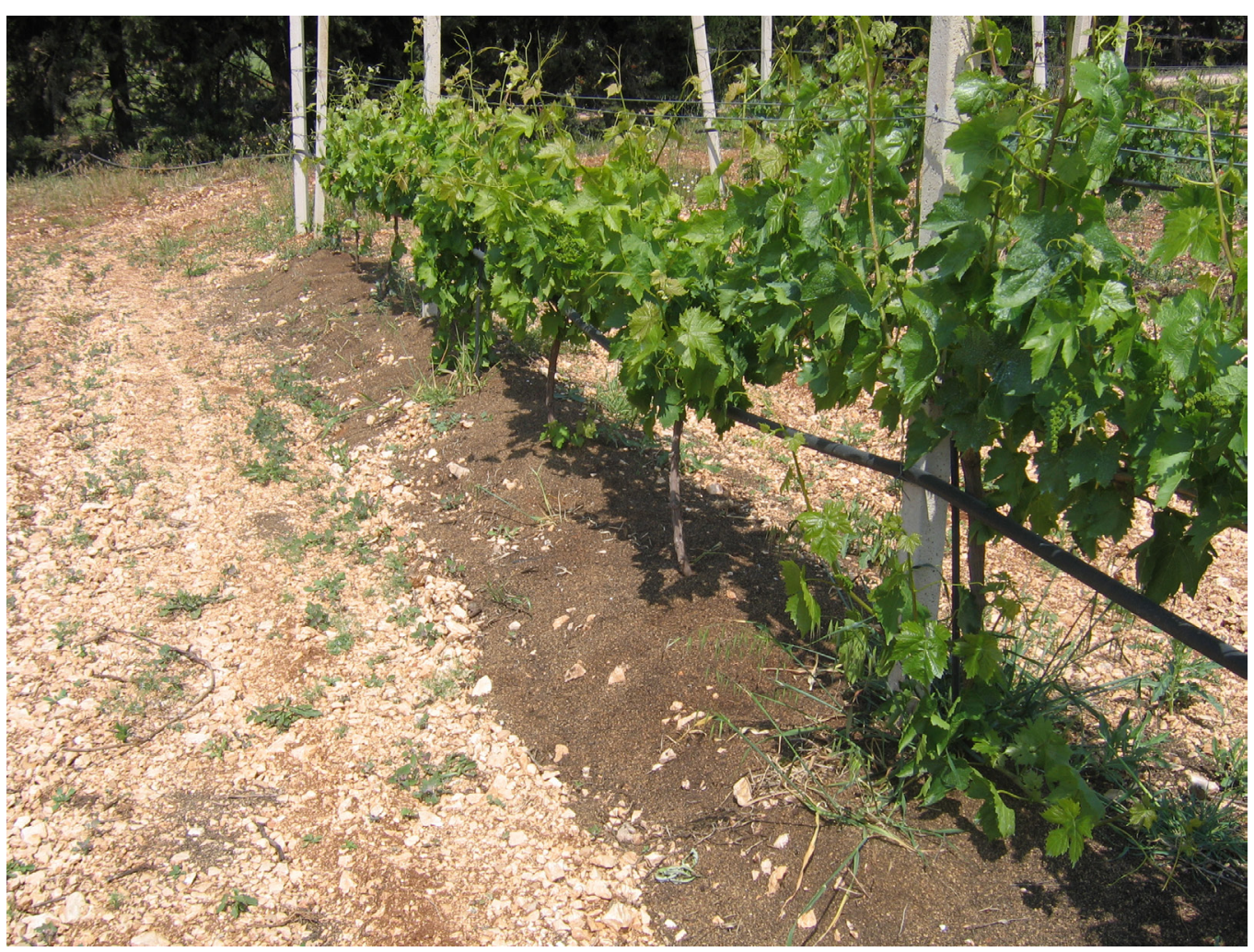

FIGURE 1

Exhausted olive pomace of $6 \mathrm{~cm}$ thick under the vines of the repository of grape varieties belonging to the Department of Soil, Plant and Food Science, University of Bari. 
$\mathrm{CaCl}_{2}$ solution $\left(\mathrm{pH}_{\mathrm{CaCl}}\right)$ with a soil/water ratio of $1: 2.5(\mathrm{w} / \mathrm{v})$ using a $\mathrm{pH}$ meter (Crison, Basic 20). The soil salinity was assessed by determination of the electrical conductivity (EC) at $25{ }^{\circ} \mathrm{C}$ on an aqueous soil extract (ratio 1:2 w/v) with a conductimeter (XS cond 510). The content of total carbonates was measured using a gas-volumetric method (Dietrich-Fruehling calcimeter), while active carbonate was determined according to the Boischot procedure (Boischot \& Hebert, 1947).

Soil organic carbon $\left(\mathrm{C}_{\text {org }}\right)$ was analysed according to the Walkley and Black method as described by Nelson and Sommers (1996). The organic matter (OM) content was calculated by multiplying the determined organic carbon by 1.724

Total nitrogen $\left(\mathrm{N}_{\text {Tot }}\right)$ was analysed using the Kjeldahl procedure, as described in Bremner (1996). Available phosphorus $\left(\mathrm{P}_{2} \mathrm{O}_{5 \text { ava }}\right)$ was determined by the Olsen method (Olsen \& Sommers, 1982). The phosphorus content was determined colorimetrically by a spectrophotometer (Megatech SP-930) at $650 \mathrm{~nm}$ absorbance using the modified ascorbic acid method (Watanabe \& Olsen, 1965).

Exchangeable cations $\left(\mathrm{Ca}_{\mathrm{ex}}, \mathrm{Mg}_{\mathrm{ex}}, \mathrm{K}_{\mathrm{ex}}\right.$ and $\left.\mathrm{Na}_{\mathrm{ex}}\right)$ were determined by means of inductively-coupled plasma - optical emission spectroscopy (ICP-OES) (ICAP 6300, Thermo Electron, UK) after soil extraction with barium chloride and triethanolamine solution buffered at $\mathrm{pH}$ 8.2. The data of the soil analysis before the trial are reported in Table 1 .

\section{Olive pomace analyses}

Exhausted olive pomace (EOP) was air-dried, ground with a mixer mill and passed through a $1 \mathrm{~mm}$ sieve. The $\mathrm{pH}$ was measured by a glass electrode in distilled water suspension at a 3:50 (w/v) EOP-to-liquid phase ratio. Electrical conductivity (EC) was determined by a conductimeter in a water extract at 1:10 (w/v) EOP-to-liquid phase ratio. Humidity and ash were determined at $105^{\circ} \mathrm{C}$ and $550{ }^{\circ} \mathrm{C}$, respectively. Organic carbon $\left(\mathrm{C}_{\mathrm{org}}\right)$ was determined according to the Ciavatta method (Ciavatta et al., 1989). Total nitrogen $\left(\mathrm{N}_{\text {Tot }}\right)$ was determined with a nitrogen analyser (Nitrogen Analyzer 2410 Series II Perkin Elmer, USA). Total $\mathrm{P}\left(\mathrm{P}_{\text {Tot }}\right)$, total cations and heavy metals were determined after digestion with $\mathrm{H}_{2} \mathrm{O}_{2}, \mathrm{HCl}$ and $\mathrm{HNO}_{3}$ using a microwave digester (MARS Xpress, CEM, USA). The concentration of metals in the digested sample was measured by means of ICP-OES (ICAP 6300, Thermo Electron, UK), and total phosphorous colorimetrically by a spectrophotometer (Megatech SP-930) at $650 \mathrm{~nm}$ according to the modified ascorbic acid method. The physicochemical characteristics of the exhausted olive pomace are given in Table 1.

\section{Flora surveys and data processing}

Weeds surveys were run between August 2008 and January 2010 in the two peak growth periods of weeds. For each plot, in a central area of $20.0 \mathrm{~m} \times 0.6 \mathrm{~m}$, weed species were identified and for each of them the cover percentage was estimated visually.

\section{Greenhouse experiments}

Fifty seeds of each of Chrysanthemum segetum L., Sonchus oleraceus L., Sinapis arvensis L., Digitaria sanguinalis (L.)
Scop., Festuca arundinacea Schreber, Chenopodoim album L., Solanum nigrum L., Diplotaxis erucoides (L.) DC. and Trifolium incarnatum L. were placed on a soil layer of $5 \mathrm{~cm}$, in trays of $30 \times 35 \times 11 \mathrm{~cm}(\mathrm{w} \times 1 \times \mathrm{h})$. Species were chosen either according to their botanical family or the size of the seeds.

In four trays the seeds were covered with a layer of $6 \mathrm{~cm}$ of exhausted olive pomace, whereas in another four trays they were covered with a $6 \mathrm{~cm}$ layer of gravel with a mean particle size of $0.5 \mathrm{~cm}$. Four trays in which the seeds were covered with soil were used as control. Each tray was considered as a single replication.

Trays were placed in a greenhouse and irrigated periodically in order to stimulate germination. After germination the seedlings were counted and removed; the trial was stopped when new seedlings were not observed for at least seven consecutive days. Data were expressed as a reduction of the emergence percentage with respect to the control, according to the formula $(\mathrm{C}-\mathrm{T}) / \mathrm{C} \times 100$, where $\mathrm{C}$ and $\mathrm{T}$ are the number of seedlings in the control and in the treatment respectively.

\section{Statistical analysis}

Variance assumptions were verified (homogeneity of variance by Levene's test, normal distribution by the Lillefors test). For data from the soil analyses, analysis of variance was performed at the $0.01 \mathrm{P}$ level and the mean values obtained for the different treatments were statistically separated by using the REGWQ test. For data from the weed surveys, analysis of variance was performed at the $0.05 \mathrm{P}$ level and the mean values obtained for the different treatments were statistically separated using Duncan's test. For the greenhouse experiment, values expressed as reduction of emergence (percentage) were arcsin transformed, analysis of variance was performed at the $0.05 \mathrm{P}$ level and the mean values were compared with the LSD test.

\section{RESULTS AND DISCUSSION}

\section{Soil analyses}

The soil is loam according to the USDA soil texture classification, following the particle analysis (Table 1). The results of the physicochemical analyses of the soil at 0 to 20 $\mathrm{cm}$ showed statistically significant differences only for $\mathrm{K}$ and $\mathrm{Mg}$ content, for $\mathrm{K}$ in the second year and for $\mathrm{Mg}$ in the first and second year respectively (Table 2). No differences were observed for parameters such as $\mathrm{pH}, \mathrm{EC}, \mathrm{C}_{\mathrm{org}}$ and $\mathrm{N}_{\mathrm{Tot}}$, and the only differences between treatments were observed for the concentrations of some of the exchangeable cations. In particular, EOP6 showed the highest values of $\mathrm{Mg}_{\mathrm{ex}}$ and $\mathrm{K}_{\mathrm{ex}}$, as a consequence of their higher content in the olive pomace (Table 1). Major changes for various soil chemical properties were measured after an olive orchard irrigation with treated wastewater (Bedbabis et al., 2014a, 2014b). The soil organic matter content in a 'Chardonnay' vineyard in South Africa in the 0 to $150 \mathrm{~mm}$ soil layer of the cover crop treatment was significantly higher than that of the mechanicallycultivated control after a period of 10 years (Fourie et al., 2007). In our trial we did not observe any significant change because of both the shorter period of time and the fast mineralisation of the organic material (olive pomace, weeds) 


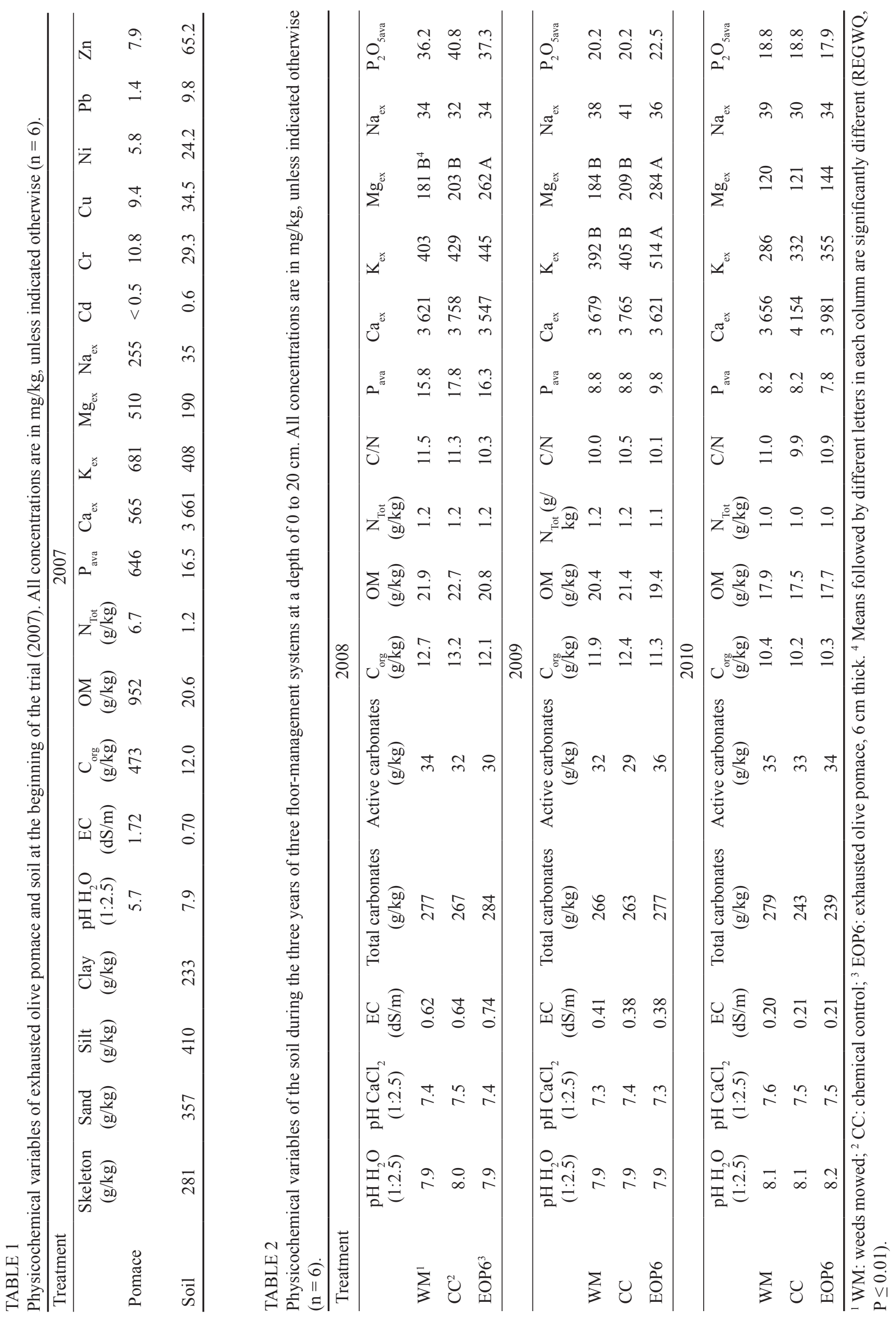


on the soil surface. However, $\mathrm{CC}$ required an application of agrochemicals, whereas WM and EOP6 were based on the re-use of organic material with a more sustainable approach. In an agricultural area close to the Puglia region, soil-protecting orchard management (SPOM) actions in kiwi and apricot orchards (i.e. cover crop, no tillage, compost application and mulching with pruning residues) increased yield and $\mathrm{N}, \mathrm{P}$ and $\mathrm{K}$ content in the soil with respect to the traditional orchard management practices (i.e. soil tillage, removing of pruning residues and mineral fertilisers) commonly adopted in the area (Montanaro et al., 2010), but with no effects on soil organic carbon, as also observed in our trial. The different vineyard managements did not have a significant effect on total soil $\mathrm{C}$ and no differences could be monitored for years, whereas labile soil $\mathrm{C}$ pools respond more rapidly to changes in floor management (Reganold et al., 2001; Haynes, 2005).

A similar trend of the soil parameters was observed at 20 to $40 \mathrm{~cm}$ (Table 3), with significant differences among treatments only for the content of $\mathrm{K}_{\mathrm{ex}}$ and $\mathrm{Mg}_{\mathrm{ex}}$, with the higher values measured in the EOP6 treatment. The changes in $\mathrm{K}_{\mathrm{ex}}$ and $\mathrm{Mg}_{\mathrm{ex}}$ content were significant along the years either for the 0 to 20 (Table 4) or the 20 to $40 \mathrm{~cm}$ layer (Table 5). The application of EOP6 increased the $\mathrm{K}_{\mathrm{ex}}$ and $\mathrm{Mg}_{\mathrm{ex}}$ content in the upper soil layer one year after application (Table 2); but after three years, in 2010, the $\mathrm{K}_{\text {ex }}$ and $\mathrm{Mg}_{\text {ex }}$ levels in EOP6 soil $(0$ to $20 \mathrm{~cm})$ were similar to that in the CC and WM soil (Table 2), suggesting that $\mathrm{K}_{\mathrm{ex}}$ and $\mathrm{Mg}_{\mathrm{ex}}$ had leached from the 0 to $20 \mathrm{~cm}$ layer down to the 20 to $40 \mathrm{~cm}$ layer (Table 3). A similar trend has been reported after mulching with bark in an apple orchard (Peck et al., 2011). Since the vineyard was not fertilised during the three experimental years, significant reductions of $\mathrm{P}_{\text {ava }}, \mathrm{K}_{\mathrm{ex}}, \mathrm{Mg}_{\mathrm{ex}}$ and $\mathrm{EC}$ were observed (Tables 4 and 5), probably as a consequence of vine absorption of elements, as recently reported for different grape varieties in Spain (Amorós et al., 2013). A long-term apple orchard floor management study reported increases in $\mathrm{C}, \mathrm{P}, \mathrm{Ca}, \mathrm{Fe}$, $\mathrm{Mn}$ and $\mathrm{pH}$ in the 0 to $20 \mathrm{~cm}$ soil layer after 12 to 14 years of biennial bark mulch applications (Yao et al., 2006).

EOP6 increased the content of both $\mathrm{K}_{\mathrm{ex}}$ and $\mathrm{Mg}_{\mathrm{ex}}$ with respect to $\mathrm{WM}$ and $\mathrm{CC}$ (Tables 4 and 5), as a consequence of the concentration of these elements in the exhausted olive pomace (Table 1). After three years the soil chemical response to the different treatments was limited, with only four soil parameters showing significant differences (Tables 4 and 5). Similar limited results were observed in a recent experiment in an almond orchard in Spain, where the soil properties showed significant differences only when cover treatments (i.e. cover crops, native vegetation) were compared to tillage systems, with the cover crops improving soil stability (Ramos et al., 2011). This positive result of mulching could be important in the case of soils subjected to rock fragmentation, a common agricultural practice in Puglia before establishing table grape vineyards (Ferrara et al., 2012). Differences among cover treatments were detected for enzymatic activity, whereas chemical and physical parameters did not show differences (Ramos et al., 2011). No significant variations were observed for the heavy metal concentrations in the soil after three years (data not shown) because of the low amount of metals, both in the exhausted olive pomace and in the soil (Table 1). These results indicate that the application of exhausted olive pomace as mulching material is not a concern with regard to either heavy metal accumulation in the soil or effects on microorganisms.

In a corn field, cover crops and manure did not significantly affect the soil organic content after a fouryear experiment, but the labile $C$ fraction was significantly increased by cover crops (Jokela et al., 2009), also improving aggregate stability and microbial biomass. However, cover crops were beneficial for corn silage systems, but it may take more than four years for some soil quality indicators to respond fully (Jokela et al., 2009). This also is a possible explanation for the limited changes in soil organic matter and other chemical parameters measured in our experiment.

The use of olive mill wastes as mulching material have shown positive effects on soil organic content (Altieri \& Esposito, 2008; López-Piñeiro et al., 2008), physical properties (El-Asswad et al., 1993; Mellouli et al., 1998; Kavdir \& Killi, 2007; Al-Widyan et al., 2010), and mineral elements (Montemurro et al., 2004; Cucci et al., 2008; López-Piñeiro et al., 2008; Uygur \& Karabatak, 2009). The application of the exhausted olive pomace as mulch could be a positive way to dispose of this material in olive oilproducing countries and to add some mineral elements for vine nutrition, as being applied as mulch at an amount similar to that used in the trial caused no negative effects either to the vine or to the soil.

The weeds, either chemically (CC) or mechanically controlled (WM), can compete with the vines for nutrients and water, thus affecting berry growth and ripening, especially in a situation of water stress (Monteiro \& Lopes, 2007). However, weed competition can balance the vegetative and reproductive activities of the grapevine, with consequent better light exposure of the clusters (reduced foliage); 'Cabernet Sauvignon' and 'Pinot noir' light-exposed clusters resulted in higher anthocyanins, phenolics and sugar and greater size (Dokoozlian \& Kliewer, 1996). But mulching also can be used to reduce weed competition with the vine and to inhibit weed seedling emergence (Fourie, 2010).

The exhausted olive pomace increased two mineral elements in the soil ( $\mathrm{K}$ and $\mathrm{Mg}$ ), whereas other mulching materials such as wood chip increased both active and slow soil $\mathrm{C}$ pools, total soil $\mathrm{C}$ and $\mathrm{N}$, earthworm activity, fruit yield and tree growth in an apple orchard (TerAvest et al., 2011). Exhausted olive pomace mulch is not used in vineyards, but effective weed suppression has recently been reported in a wine grape vineyard in the Puglia region (Ferrara et al., 2012). Weed reduction in orchards mulched with various biomasses has been reported recently in a study conducted in the USA (Granatstein \& Mullinix, 2008), and the use of bark mulch was effective in increasing the soil organic matter with respect to mechanical weed control in an apple orchard (Peck et al., 2011).

In recent research in two Californian vineyards, the use of a mulch from mowed cover crops in the alleys was very effective in weed suppression, and it was reported that grape yields and profits under a mulched cover crop system were similar to, and often exceeded, what was observed in conventional tillage and herbicide systems (Steinmaus et al., 2008). 


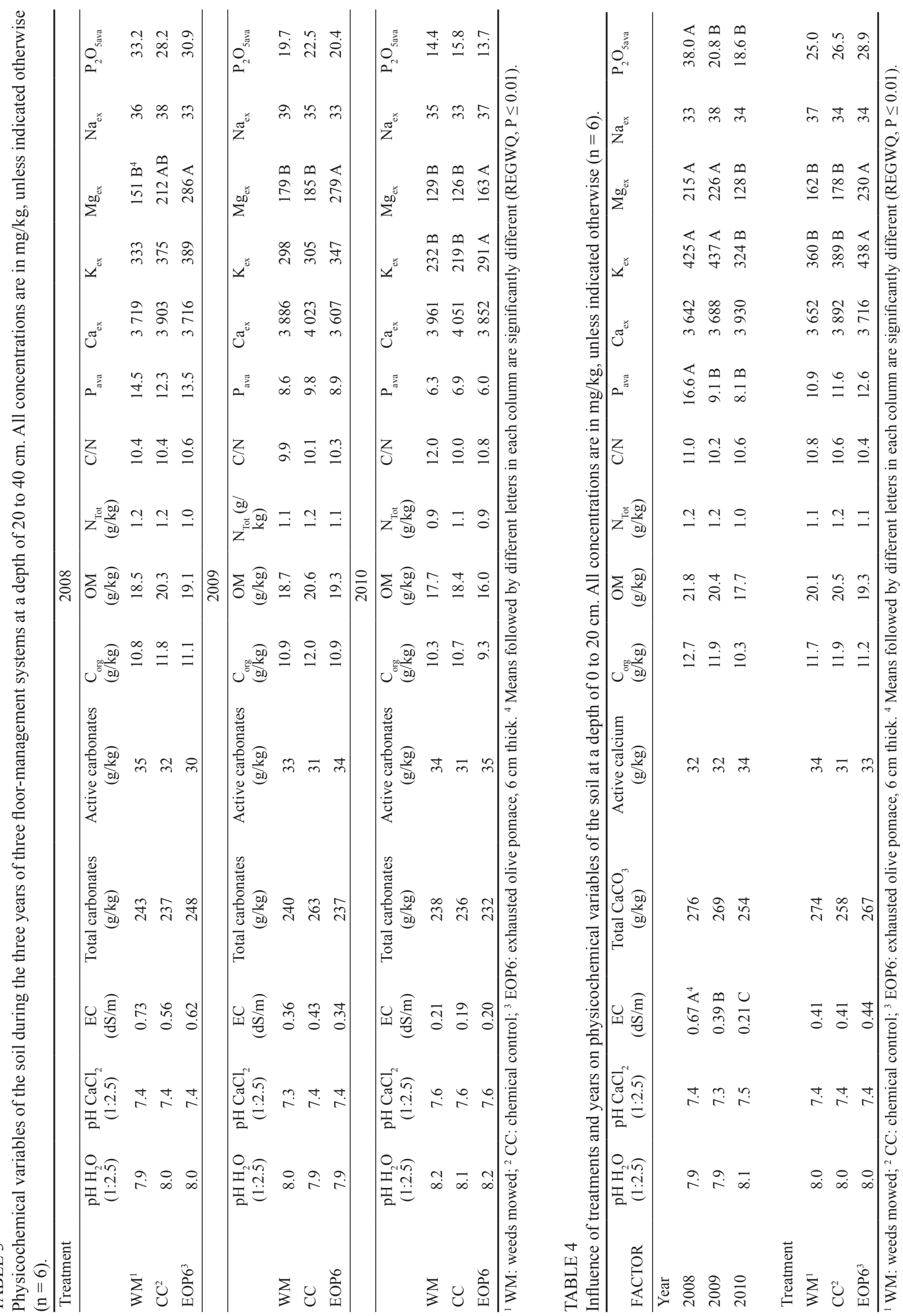




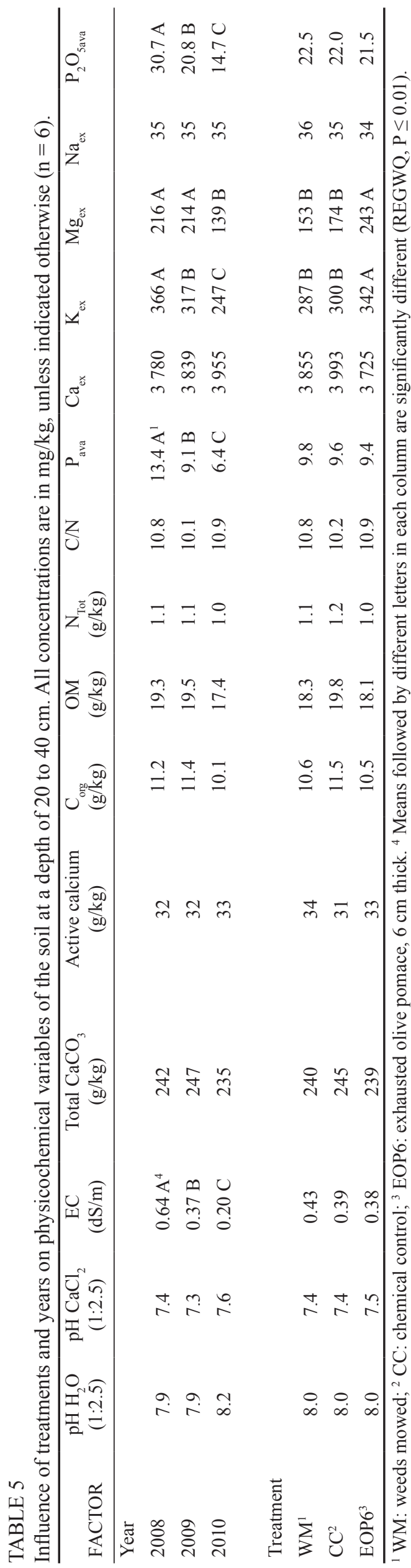

Grape growers generally control weeds under vines with cultivation and/or herbicides, with high economic and environmental 'costs'. In particular, cultivation can significantly change soil characteristics and root growth, as a consequence successively influencing soil nitrogen (N) dynamics and loss (Jackson et al., 2003).

\section{Weed survey}

The results of the weed surveys conducted during the three years are reported in Table 6. In the first survey (2008-0801), the most abundant weeds were Bidens tripartita L., Chenopodium album L. and Convolvulus arvensis L. The lowest cover percentage of B. tripartita L. was estimated in the plots mulched with EOP6 (3.3\%); with regard to $C$. album L., the lowest infestation was found in both EOP6 and WM plots. On 2008-10-21 the lowest covering of Calendula arvensis L. (3.0\%) was in the EOP6 plot, whereas the lowest cover percentage of Hordeum murinum L. was estimated in both the CC and EOP6 plots. In the survey of 2009-0630, the presence of Avena sterilis L., Chondrylla juncea L., Conyza canadensis (L.) Cronq. and Sonchus tenerrimus L. measured in the CC and EOP6 plots was significantly lower than the values measured in the WM management plot. The cover percentages of B. tripartita L. and C. album L. were lower under EOP6 management, but not statistically different from the values in WM management. The cover percentage of Cirsium arvense (L.) Scop. was significantly higher in EOP6 with respect to CC and WM on 2009-06$30(27.9 \%)$, whereas it was significantly higher than CC and similar to WM on 2010-01-08 (10.5\%). Moreover, in this last survey, the cover percentage of $C$. canadensis (L.) Cronq. estimated in the WM and EOP6 plots was significantly lower with respect to values measured in the $\mathrm{CC}$ management plot $(6.3 \%)$.

\section{Greenhouse experiments}

The emergence of $C$. segetum Hill, S. oleraceus L., $S$. arvensis $\mathrm{L}$. and $T$. incarnatum $\mathrm{L}$. was reduced by both EOP6 and gravel, although with different effectiveness (Table 7). Only EOP6 was able to partly reduce the emergence of $D$. sanguinalis and $F$. arundinacea $(67.6 \%$ and $38.7 \%$ respectively). The emergence of $C$. segetum Hill, $S$. oleraceus L. and $S$. arvensis L. was completely inhibited $(100.0 \%)$ by the exhausted olive pomace, whereas gravel reduced the emergence of weeds by $61.5,40.0$ and $68.9 \%$ respectively (Table 7). The emergence of T. incarnatum L. was reduced by $59.8 \%$ and by $12.8 \%$ with EOP 6 and gravel respectively.

For all these species, the inhibition observed with EOP6 was statistically higher than in the control (gravel), although the thickness of these two materials were similar. This observation might lead us to assume that the olive pomace could act both physically (thickness) and chemically, through phytotoxic compounds released during its degradation, as already reported for rye mulch on Amaranthus retroflexus L. and Portulaca oleracea L. (Schulz et al., 2012).

The emergence of $C$. album L., S. nigrum L. and $D$. erucoides L. was not affected by EOP6 and the control (data not shown). The different responses of the test species could be due to morphological characteristics of the seeds and 


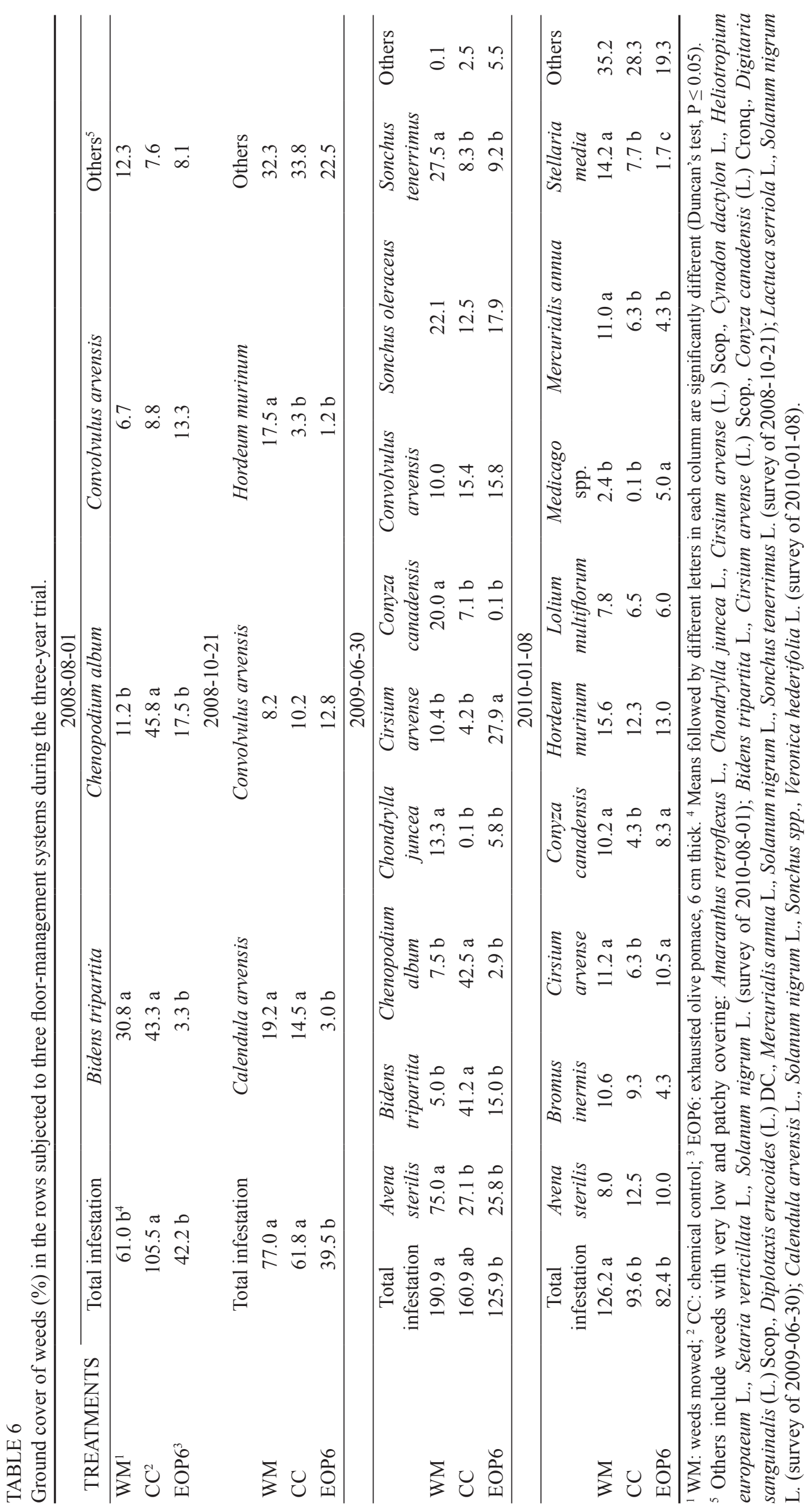


TABLE 7

Effect of $6 \mathrm{~cm}$ thick exhausted olive pomace (EOP6) and gravel on reduction of seed emergence (\%) with respect to the control (soil) in the greenhouse experiment.

\begin{tabular}{lrr}
\hline Species & Gravel & EOP6 $^{1}$ \\
\hline Chrysanthemum segetum L. & $61.5 \mathrm{~b}^{2}$ & $100.0 \mathrm{a}$ \\
Sonchus oleraceus L. & $40.0 \mathrm{~b}$ & $100.0 \mathrm{a}$ \\
Sinapis arvensis L. & $68.9 \mathrm{~b}$ & $100.0 \mathrm{a}$ \\
Digitaria sanguinalis (L.) Scop. & $0.0 \mathrm{~b}$ & $67.6 \mathrm{a}$ \\
Festuca arundinacea Schreber & $0.0 \mathrm{~b}$ & $38.7 \mathrm{a}$ \\
Trifolium incarnatum L. & $12.8 \mathrm{~b}$ & $59.8 \mathrm{a}$ \\
\hline
\end{tabular}

${ }^{1}$ EOP6: exhausted olive pomace, $6 \mathrm{~cm}$ thick. ${ }^{2}$ Means followed by different letters in each row are significantly different (LSD test, $\mathrm{P} \leq 0.05)$.

seedlings, or specific physiological aspects (Inderjit \& Duke, 2003).

\section{CONCLUSIONS}

Soil management with the exhausted olive pomace showed positive effects on some soil chemical parameters, in particular the increase in $\mathrm{K}$ and $\mathrm{Mg}$ content. As expected, the other two soil management systems did not show any influence on soil chemical properties. Exhausted olive pomace was able to control the emergence of many weeds and, in each survey, showed effects similar to those obtained with both chemical and mechanical weed control. These results are very remarkable because soil mulched with exhausted olive pomace was not subjected to other treatments or the reapplication of the material for three years, whereas in the other treatments weeds were chemically or mechanically controlled repeatedly over the years. In olive oil-producing countries (Italy, Spain, Greece, etc.), olive pomace originates from three-phase systems and is extracted successively for obtaining olive pomace oil. The exhausted olive pomace could be used as fuel or, as demonstrated in our research, can be used as mulching material to exert good control over weeds as part of more sustainable management of the vineyard.

\section{LITERATURE CITED}

Al-Widyan, M.I., Al-Abed, N. \& Al-Jalil, H., 2010. Effect of composted olive cake on soil physical properties. Commun. Soil Sci. Plan. 36, 1199 1212 .

Alburquerque, J.A., Gonzálvez, J., García, D. \& Cegarra, J. (2006) Composting of a solid olive-mill by product ("alperujo") and the potential of the resulting compost for cultivating pepper under commercial conditions. Waste Management 26, 620-626.

Altieri, R., \& A. Esposito. 2008. Olive orchard amended with two experimental olive mill wastes mixtures: Effects on soil organic carbon, plant growth and yield. Bioresource Technol. 99: 8390-8393.

Amorós, J.A., Pérez-de-los Reyes, C., García Navarro, F.J., Bravo, S., Chacón, J.L., Martínez, J. \& Jiménez Ballesta, R., 2013. Bioaccumulation of mineral elements in grapevine varieties cultivated in "La Mancha". J. Plant Nutr. Soil Sci., 176, 843-850. doi:10.1002/jpln.201300015.
Bedbabis, S., Ben Rouina, B., Boukhris, M. \& Ferrara, G., 2014a. Effect of irrigation with treated wastewater on soil chemical properties and infiltration rate. J. Environ. Manage. 133, 45-50. http://dx.doi.org/10.1016/j. jenvman.2013.11.007.

Bedbabis, S., Ben Rouina, B., Boukhris, M. \& Ferrara, G., 2014b. Effects of irrigation with treated wastewater on root and fruit mineral elements of Chemlali olive cultivar. Sci. World J., 2014, 1-8. http://dx.doi. org/10.1155/2014/973638.

Bhowmika, P.C. \& Inderjitb, 2003. Challenges and opportunities in implementing allelopathy for natural weed management. Crop Protect. 22, 661-671.

Boischot, P. \& Hebert, J., 1947. Determination of available calcium in soil by the ammonium oxalate method and its use to determine the readily assimilable calcium of liming materials. Ann. Agronomy 17, 521-525.

Bremner, J.M., 1996. Nitrogen - Total. In: Sparks, D.L., Page, A.L., Helmke, P.A., Loeppert, R.H., Soltanpour, P.N., Tabatabai, M.A., Johnston C.T. \& Sumner M.E. (eds). Methods of Soil Analysis. Part 3. Chemical Methods. SSSA and ASA, Madison, Wisconsin. pp. $1085-1121$.

Brunetti, G., Plaza, C. \& Senesi, N., 2005. Olive pomace amendment in Mediterranean conditions: Effects on soil and humic acid properties and wheat (Tritiucm turgidum L.) yield. J. Agr. Food Chem. 53, 6730-6736.

Carter, A.D., Hollis, J.M., Thompson, T.R.E., Oakes, D.B. \& Binneyu, R., 1991. Pesticide contamination of water sources: current policies for protection and a multi-disciplinary proposal to aid future planning. Brighton Crop Prot. Conf. Weeds 2, 491-498.

Ciavatta, C., Antisari, L.V. \& Sequi, P., 1989. Determinations of organic carbon in soils and fertilizers. Commun. Soil Sci. Plant Anal. 20, 759-773.

Cousens, R. \& Mortimer, M., 1995 ( $1^{\text {st }}$ ed). Dynamics of weed populations. Cambridge University Press, Cambridge.

Cucci, G., Lacolla, G. \& Caranfa, L., 2008. Improvement of soil properties by application of olive oil waste. Agron. Sustain. Dev. 28, 521-526.

Darmency, H. \& Gasquez, J., 1990. The fate of herbicide resistant genes in weeds. In: Green, M.B., LeBaron, H.M. \& Moberg, W.K. (eds). Managing resistance to agrochemicals: From fundamental research to practical strategies. American Chemical Society, Washington DC. pp. 353-364.

Dokoozlian, N.K. \& Kliewer, W.M., 1996. Influence of light on grape berry growth and composition varies during fruit development. J. Am. Soc. Hortic. Sci. 121, 869-874.

El-Asswad, R.M., Said, A.O. \& Mornag, M.T., 1993. Effect of olive oil cake on water holding capacity of sandy soils in Libya. J. Arid Environ. 24, 409-413.

Ferrara, G., Farrag, K. \& Brunetti, G., 2012. The effects of rock fragmentation and/or deep tillage on soil skeletal material and chemical properties in a Mediterranean climate. Soil Use Manage. 28, 394-400. http:// dx.doi.org/10.1111/j.1475-2743.2012.00423.x

Ferrara, G., Fracchiolla, M., Al Chami, Z., Camposeo, S., Lasorella, C., Pacifico, A., Aly, A. \& Montemurro, P., 2012. Effects of mulching materials on soil and performance of cv. Nero di Troia grapevines in the Puglia region, Southeastern Italy. Am. J. Enol. Viticult. 63, 269-276.

Fourie, J.C., 2010. Soil management in the Breede River Valley wine grape region, South Africa. 1. Cover crop performance and weed control. S. Afr. J. Enol. Vitic. 31, 14-21.

Fourie, J.C., Louw, P.J.E. \& Agenbag, G.A., 2007. Cover crop management in a Chardonnay/99 Richter vineyard in the Coastal region, South Africa. 3. Effect of different cover crop and cover crop management practices on organic matter and macro-nutrient content of a medium textured soil. S. Afr. J. Enol. Vitic. 28, 61-68.

Gee, W. \& Bauder, J.W., 1986. Particle size analysis. In: Klute A. (ed). Methods of soil analysis. Part 1: Physical and mineralogical methods. ASA Monograph, vol. 9, Madison, WI. pp. 383 - 411. 
Gómez-Muñoz, B., Hatch, D.J., Roland Bol, R. \& García-Ruiz, R., 2013. Agrochemical characterization, net $\mathrm{N}$ mineralization, and potential $\mathrm{N}$ leaching of composted olive-mill pomace currently produced in southern Spain. J. Plant Nutr. Soil Sci. 176, 655-664.

Granatstein, D. \& Mullinix, K., 2008. Mulching options for Northwest organic and conventional orchards. Hort. Sci. 43, 45-50.

Haynes, R.J., 1980. Influence of soil management practice on the orchard agro-ecosystem. Agro-Ecosystems 6, 3-32.

Haynes, R.J., 2005. Labile organic matter fractions as central components of the quality of agricultural soils: An overview. Adv. Agron. 85, 221-268.

Henkes, R., 1997. Handling herbicide resistance. The Furrow 102, 8-11.

Inderjit, \& Duke S.O., 2003. Ecophysiological aspects of allelopathy. Planta 217, 529-539.

Jackson, L.E., Calderón, F.J., Steenwerth, K.L., Scow, K.M. \& Rolston, D.E., 2003. Responses of soil microbial processes and community structure to tillage events and implications for soil quality. Geoderma 114, 305-317.

Jokela, W.E., Grabber, J.H., Karlen, D.L., Balser, T.C. \& Palmquist, D.E., 2009. Cover crop and liquid manure effects on soil quality indicators in a corn silage system. Agron. J. 101, 727-737.

Kavdir, Y. \& Killi, D., 2007. Influence of olive oil solid waste applications on soil $\mathrm{pH}$, electrical conductivity, soil nitrogen transformations, carbon content and aggregate stability. Bioresource Technol. 99, 2326-2332.

LeBaron, H.M., 1991. Distribution and seriousness of herbicide-resistant weed infestations worldwide. In: Caseley, J.C., Cussans, G.W. \& Atkin, R.K. (eds). Herbicide resistance in weeds and crops. Butterworth-Heinemann, Boston. pp. $27-43$.

LeBaron, H.M. \& McFarland, J.E., 1990. Herbicide resistance in weeds and crops: An overview and prognosis. In: Green, M.B., LeBaron, H.M. \& Moberg, W.K. (eds). Managing resistance to agrochemicals: From fundamental research to practical strategies. American Chemical Society, Washington DC. pp. 336-352

López-Piñeiro, A., Albarràn, A., Rato Nunes, J.M. \& Barreto, C., 2008. Short and medium-term effects of two-phase olive mill waste application on olive grove production and soil properties under semiarid Mediterranean conditions. Bioresource Technol. 99, 7982-7987.

Major, C.S., 1992. Addressing public fears over pesticides. Weed Technol. $6,471-472$.

Mellouli, H.J., Hartmann, R., Gabriels, D. \& Cornelis, W.M., 1998. The use of olive mill effluents ("margines") as soil conditioner mulch to reduce evaporation losses. Soil Till. Res. 49, 85-91.

Merwin, I.A., Rosenberger, D.A., Engle, C.A., Rist, D.L. \& Fargione, M., 1995. Comparing mulches, herbicides, and cultivation as orchard groundcover management systems. Hort. Technol. 5, 151-158.

Montanaro, G., Celano, G., Dichio B. \& Xiloyannis, C., 2010. Effects of soil-protecting agricultural practices on soil organic carbon and productivity in fruit tree orchards. Land Degrad. Develop. 21, 132-138.

Monteiro, A. \& Lopes, C.M., 2007. Influence of cover crop on water use and performance of vineyard in Mediterranean Portugal. Agr. Ecosyst. Environ. 121, 336-342.

Montemurro, F., Convertini, G. \& Ferri, D., 2004 Mill wastewater and olive pomace compost as amendments for rye-grass. Agronomie 24, 481-486.

Moonen, C.L. \& Barberi, P., 2004. Size and composition of the weed seedbank after 7 years of different cover-crop-maize management systems. Weed Res. 44:3, 163-177.
Nelson, D.W. \& Sommers L.E., 1996. Total carbon, organic carbon, and organic matter. In: Sparks, D.L., Page, A.L., Helmke, P.A., Loeppert, R.H., Soluanpour, P.N., Tabatabai, M.A., Johnston, C.T. \& Sumner, M.E. (eds). Methods of soil analysis part 3: Chemical methods. Soil Science Society of America, Inc. and American Society of Agronomy, Inc., Madison, Wisconsin. pp. $961-1010$.

Olsen S.R. \& Sommers E.L., 1982. Phosphorus soluble in sodium bicarbonate. In: Page, A.L., Miller, P.H. \& Keeney D.R. (eds). Methods of Soil Analysis, Part 2. Chemical and Microbiological Properties. Agronomy Monograph 9, ASA and SSSA, Madison, WI. pp. $403-430$.

Peck, G.M., Merwin, I.A., Thies, J.E., Schindelbeck, R.R. \& Brown, M.G., 2011. Soil properties change during the transition to integrated and organic apple production in a New York orchard. Appl. Soil Ecol. 48, 18-30.

Powles, S.B., Preston, C., Bryan, I.B. \& Jutsum, A.R., 1997. Herbicide resistance impact and management. Adv. Agron. 58, 57-93.

Ramos, M.E., Robles, A.B., Antonio Sánchez-Navarro, A. \& GonzálezRebollar, J.L., 2011. Soil responses to different management practices in rainfed orchards in semiarid environments. Soil Till. Res. 112, 85-91.

Reganold, J.P., Glover, J.D., Andrews, P.K. \& Hinman, H.R., 2001. Sustainability of three apple production systems. Nature 410, 926-930.

Rinaldi, M., Rana, G. \& Introna, M., 2003. Olive mill wastewater spreading in southern Italy: Effects on a durum wheat crop. Field Crop Res. 84, 319326 .

Saviozzi, A., Levi-Minzi, R., Cardelli, R., Biasci, A. \& Riffaldi, R., 2001. Suitability of moist olive pomace as soil amendment. Water Air Soil Poll. $128,12-22$.

Schulz, M., Marocco, A. \& Tabaglio, V., 2012. BOA detoxification of four summer weeds during germination and seedling growth. J. Chem. Ecol. 38, 933-946.

Sparks, D.L., Page, A.L., Helmke. P.A., Loeppert, R.H., Soltanpour, P.N., Tabatabai, M.A., Johnston, C.T. \& Sumner, M.E., 1996. Methods of soil analysis. Part 3. Chemical methods. SSSA Book Ser. 5. SSSA and ASA, Madison, WI.

Steinmaus, S., Elmore, C.L., Smith, R.J., Donaldson, D., Weber, E.A., Roncoroni, J.A. \& Miller, P.R.M., 2008. Mulched cover crops as an alternative to conventional weed management systems in vineyards. Weed Res. 48, 273-281.

Teasdale, J.R. \& Mohler, C.L., 2000. The quantitative relationship between weed emergence and the physical properties of mulches. Weed Sci. 48, 385392.

TerAvest, D., Smith, J.L., Carpenter-Boggs, L., Granatstein, D., Hoagland, L. \& Reganold, J.P., 2011. Soil carbon pools, nitrogen supply, and tree performance under several groundcovers and compost rates in a newly planted apple orchard. Hort. Sci. 46, 1687-1694.

Uygur, V. \& Karabatak, I., 2009. The effect of organic amendments on mineral phosphate fractions in calcareous soils. J. Plant Nutr. Soil Sci. 172, $336-345$.

Van Huystteen, L. \& Weber, H.W., 1980. The effect of selected minimum and conventional tillage practices in vineyard cultivation on vine performance. S. Afr. J. Enol. Vitic. 1, 77-83.

Verdú, A.M. \& Mas, M.T., 2007. Mulching as an alternative technique for weed management in mandarin orchard tree rows. Agron. Sustain. Dev. 27, $367-375$.

Watanabe, F.S. \& Olsen, S.R., 1965. Test of an ascorbic acid method for determining phosphorus in water and $\mathrm{NaHCO}_{3}$ extracts from soil. Soil Sci. Soc. Am. Proc. 29, 677-678.

Yao, S., Merwin, I.A., Bird, G.W., Abawi, G.S. \& Thies, J.E., 2006. Soil fumigation and compost amendment alter soil microbial community composition but do not improve tree growth or yield in an apple replant site. Soil Biol. Biochem. 38, 587-599. 